\title{
Pengembangan Sistem Perpustakaan Universitas Muhammadiyah Malang Berbasis Android Dengan Metode Waterfall
}

\author{
Muhammad IIham ${ }^{*}$, Gita Indah Marthasari ${ }^{2}$, Ilyas Nuryasin ${ }^{3}$ \\ 1,2,3Teknik Informatika/Universitas Muhammadiyah Malang \\ muhammadilham120@gmail.com¹, gita@umm.ac.id², ilyasnuyasin@gmail.com³
}

\begin{abstract}
Abstrak
Perpustakaan adalah sumber ilmu pengetahuan dan sarana penunjang pada setiap instansi pendidikan terutama dalam pembahasannya ini perpustakaan yang ada pada perguruan tinggi atau universitas. Dengan adanya perpustakaan maka akan memudahkan mahasiswa dalam mencari berbagai informasi mengenai belajar mengajar, dan juga akan meningkatkan dalam proses belajar mengajar. Asosiasi Penyelenggara Jasa Internet Indonesia (APPJI) pada surveynya dari beberapa tahun ini menyatakan penggunaa pada perangkat mobile memiliki peningkatan yang sangat besar. Tercatat dari tahun 2013 sampai 2017 memiliki peningkatan yang sangat besar yaitu 61,26 juta jiwa pengguna internet di Indonesia. Perilaku pengguna internet berdasarkan perangkat yang digunakan untuk mengakses internet yaitu $44.16 \%$ dalam penggunaan perangkat mobile, perangkat mobile dan komputer ataulaptop $4.49 \%$, pengunaan perangkat mobile dan komputer sebesar $39.28 \%$. Hal ini berarti perilaku pengguna internet di Inonesia sangat dominan mengakses internet melalui perangkat mobile. Apalagi statistic menunjukkan bahwa pengguna mobile internet juga semakin meningkat dari tahun ketahun. Sebelumnya sudah ada sistem perpustakaan pada Universitas Muhammadiyah Malang berbasis web. Tetapi dalam hal ini kecenderungan perilaku pengguna internet dalam penggunaan perangkat mobile, maka Perpustakaan Universitas Muhammadiyah Malang memiliki peluang yang sangat besar dalam mengembangkan dan meningkatkan pelayanan dalam memenuhi kebutuhan mahasiswa dalam mencari kebutuhan informasi.
\end{abstract}

Kata Kunci: Sistem Perpustakaan, Android, Metode Waterfall, Pengujian Black-box

\begin{abstract}
The library is a source of knowledge and supporting facilities in each educational institution, especially in this discussion the library is at a college or university. With the library, it will facilitate students in finding various information about teaching and learning, and will also improve the teaching and learning process. The Indonesian Internet Service Providers Association (APPJI) in its survey of several years stated that the use of mobile devices has a very large increase. Recorded from 2013 to 2017 has a very large increase of 61.26 million internet users in Indonesia. The behavior of internet users based on the device used to access the internet is $44.16 \%$ in the use of mobile devices, mobile devices and computers ortop $4.49 \%$, the use of mobile devices and computers by $39.28 \%$. This means that the behavior of internet users in Indonesia is very dominant in accessing the internet through mobile devices. Moreover statistics show that mobile internet users are also increasing from year to year. Previously there was a library system at the University of Muhammadiyah Malang web-based. But in this case the tendency of the behavior of internet users in the use of mobile devices, the Muhammadiyah University Library of Malang has a huge opportunity in developing an improving services in meeting the needs of students in finding information needs.
\end{abstract}

Keywords: Library System, Android, Waterfall method, Black-box test

\section{Pendahuluan}

Universitas Muhammadiyah Malang atau sering kita sebut UMM adalahsalah satu perguruan tinggi swasta terbesar se-Jawa Timur dan juga Universitas terbaik di Indonesia dengan akreditas "A" yang terletak di kota Malang. Kampus III menjadi pusat dan kampus utama dari Universitas Muhammadiyah Malang yang terletak dekat dengan terminal Landungsari. Untuk 
menunjang dalam belajar mengajar Universitas Muhammadiyah Malang memiliki fasilitas salah satunya perpustakaan.

Perpustakaan adalah sumber ilmu pengetahuan dan sarana penunjang pada setiap instansi pendidikan terutama dalam pembahasannya ini perpustakaan yang ada pada perguruan tinggi atau universitas. Dengan adanya perpustakaan maka akan memudahkan mahasiswa dalam mencari berbagai informasi mengenai belajar mengajar, dan juga akan meningkatkan dalam proses belajar mengajar. Didalam perpustakaan terdapat bagian-bagian hal pengembangan, pengelolaan, pelayanan terhadap mahasiswa, dan pemeliharaan [1]. Dari tahun ketahun perpustakaan harus meningkatkan dari semua aspek tidak terkecuali dari aspek pengembangan sistem informasi agar dapat meningkatkan pendidikan yang maksimal terutama dalam hal belajar mengajar kepada mahasiswa. Salah satu langkah dalam peningkatan dalam aspek sistem pengolahan data yang tepat serta akurat [2].

Perkembangan sistem operasi pada mobile android yang pada beberapa tahun ini meningkat, dalam hal ini sudah hamper semua kalangan telah menggunakan perangkat mobile. Tidak terkecuali pada remaja yang sudah menempuh pendidikan perkuliahan [3][1]. Asosiasi Penyelenggara Jasa Internet Indonesia (APPJI) pada surveynya dari beberapa tahun ini menyatakan penggunaa pada perangkat mobile memiliki peningkatan yang sangat besar. Tercatat dari tahun 2013 sampai 2017 memiliki peningkatan yang sangat besar yaitu 61,26 juta jiwa pengguna internet di Indonesia. Perilaku pengguna internet berdasarkan perangkat yang digunakan untuk mengakses internet yaitu $44.16 \%$ dalam penggunaan perangkat mobile, perangkat mobile dan komputer ataulaptop $4.49 \%$, pengunaan perangkat mobile dan komputer sebesar $39.28 \%$. Hal ini berarti perilaku pengguna internet di Inonesia sangat dominan mengakses internet melalui perangkat mobile. Apalagi statistic menunjukkan bahwa pengguna mobile internet juga semakin meningkat dari tahun ke tahun [4].

Pelayanan utama perpustakaan berfokus kepada pengguna. Kegiatan perpustakaan dimulai dari collecting, processing, dan distributing untuk memberikan kepuasan kepada pengguna [5]. Sebelumnya sudah ada sistem perpustakaan pada Universitas Muhammadiyah Malang berbasis web. Tetapi dalam hal ini kecenderungan perilaku pengguna internet dalam penggunaan perangkat mobile, maka Perpustakaan Universitas Muhammadiyah Malang memiliki peluang yang sangat besar dalam mengembangkan dan meningkatkan pelayanan dalam memenuhi kebutuhan mahasiswa dalam mencari kebutuhan informasi.

Dari uraian di atas maka maka penelitian ini dimaksudkan untuk mempermudah pengguna dan untuk mengembangkan sistem pada perpustakaan tersebut. Dengan menggunakan teknologi informasi yang memfokuskan pada peningkatan pelayanan kepada pengguna, sistem informasi itu berupa aplikasi mobile. Diharapkan dengan adanya aplikasi ini para pengguna menjadi lebih dipermudah dan menjadi lebih efisien dalam melakukan hal berkaitan dengan pengelolaan perpustakaan.

\section{Tinjauan Pustaka}

\subsection{Perpustakaan}

Perpustakaan secara singkat dapat diartikan sebagai kumpulan informasi atau koleksi yang bersifat ilmu pengetahuan, hiburan, dan reaksi yang berupa buku, jurnal dan makalah. Oleh karena itu perpustakaan pada saat ini didefinisikan kembali sebagai tempat untuk mencari atau mengakses informasi dalam format apapun, dan apakah informasi itu disimpan dalam gedung perpustakaan itu ataupun tidak [6]. Perpustakaan Universitas Muhammadiyah Malang adalah bagian dari sumber belajar dan sarana penunjang yang ada pada Universitas Muhammadiyah Malang. Karena dengan adanya perpustakaan mahasiswa dapat dengan mudah mencari informasi dan ilmu pengetahuan, dan juga akan meningkatkan dalam proses belajar mengajar.

\subsection{Software Developtment Life Cycle (SDLC) Waterfall Model}

Metode ini adalah metode dalam pengembangan atau pembuatan perangkat yang sering dilakukan oleh para peneliti sistem. Metode waterfall juga merupakan salah satu metode dalam SDLC (System Development Life Cycle) yang mempunyai ciri khas dalam setiap fase pengerjaannya. Dalam metode waterfall harus menyelesaikan setiap fase terlebih dahulu sebelum melanjutkan kefase berikutnya. Artinya dalam pengerjaannya memfokuskan terhadap masing-masing fase dan pengerjaan tiap fase dapat dilakukan dengan maksimal karena tidak adanya pengerjaan yang sifatnya parallel [2][7].

REPOSITOR, Vol. 2, No. 6, Juni 2020: 745-756 
Metode ini memiliki beberapa proses yang berurutan dan teratur dalam pengembangannya dan akan dijelaskan Gambar 1 di bawah ini.



Gambar 1. Metode Waterfall

a. Requirement/ Perencanaan

Pada tahap ini adalah tahap pendahuluan yang akan dilakukan sebelum masuk ke dalam tahap selanjutnya. Dalam tahap ini pengembang sistem memerlukan komukasi terhadap klien untuk tujuan mencari data kebutuhan dan memahami perangkat lunak yang diharapkan oleh klien dan batasan batasan apa saja nantinya dalam pembuatan perangkat lunak. Data kebutuhan itu berupa informasi yang dilakukan dengan cara wawancara, diskusi, atau survey langsung dan kemudian akan dilakukan analisa yang menghasilkan kebutuhan yang dibutuhkan oleh klien [6]. b. Design System (desain sistem)

Pada tahap ini merupakan kelanjutan dari tahap sebelumnya yang sudah dilakukan, tahap ini merupakan spesifikasi dari tahap sebelumnya yang akan dipelajari oleh pengembang dalam membuat sistem nantinya. Desain sistem membantu pengembang dalam mendefinisikan dari arsitektur dari sistem secara keseluruhan [8].

c. Pengkodean dan Tes (Kode program atau proses implementation)

Pada tahap ini adalah tahap pembuatan aplikasi yang akan dibuat oleh pengembang, pengaplikasian apa yang sudah didapat dari tahap sebelumnya agar dapat membangun aplikasi yang sesuai dengan apa yang dibutuhkan oleh pengguna [8].

d. Integrasi dan Sistem Tes (Penerapan serta pengujian pada Program)

Pada tahap ini adalah tahap dimana aplikasi yang sudah dibuat di dalam tahap sebelumnya dilakukan testing dan pengujian. Tahapan ini adalah tahapan terakhir dari pengembangan perangkat lunak, setelah tahap pengujian dan testing perangkat lunak akan dikirimkan ke klien [8].

e. Operasi dan Pemeliharaan Sistem

Pada tahap ini adalah tahapan pemeliharaan sistem setelah perangkat lunak dikirimkan kepada klien. Pemeliharaan ini termasuk dalam memperbaiki kesalahan-kesalahan yang ada pada sistem yang tidak ditemukan dalam tahap pengujian dan testing [8].

\subsection{Java}

Java adalah multi purpose programming, yaitu bahasa pemrogramanyang dapat digunakan dalam beberapa sistem operasi. Java memiliki edisi yang lengkap untuk semua bahasa pemrograman, yaitu pemrograman database atau enterprise, pemrograman desktop, dan pemrograman mobile. Dalam Java, ada tiga komponen - komponen yang sangat penting, yang merupakan komponen utama java diantaranya Programming-language specification, Applicationprogramming interface, Virtual-machine specification.

\subsection{RDBMS}

RDBMS adalah suatu program yang melayani sistem basis data relasional yang entitas utamanya terdiri table - table, yang dapat digunakan secara gratis yang berada di bawah GPL (General Public License). MySQL adalah turunan dari SQL (Structured Query Language) yang mempunyai konsep utama basis data yang merupakan pengoperasian dari basis data, yang berfungsi untuk memudahkan dalam pengoperasian pemilihan atau pembuatan data, seleksi dan input data. Dalam hal pengoperasian basis data transaksional maupun operasi basis data non- 
transaksional yang didukung dengan kemudahan cara kerja pengoptimasiannya dalam melakukan perintah - perintah SQL yang telah dibuat oleh programmer [7].

\section{Metodologi Penelitian}

\subsection{Analysis}

Pada tahap ini penulis mengumpulkan kebutuhan untuk sistem Perpustakaan Universitas Muhammadiyah Malang ini, dengan metode observasi dan wawancara, sehingga menghasilkan berupa Use Case yang dapat dilihat pada Gambar 2.

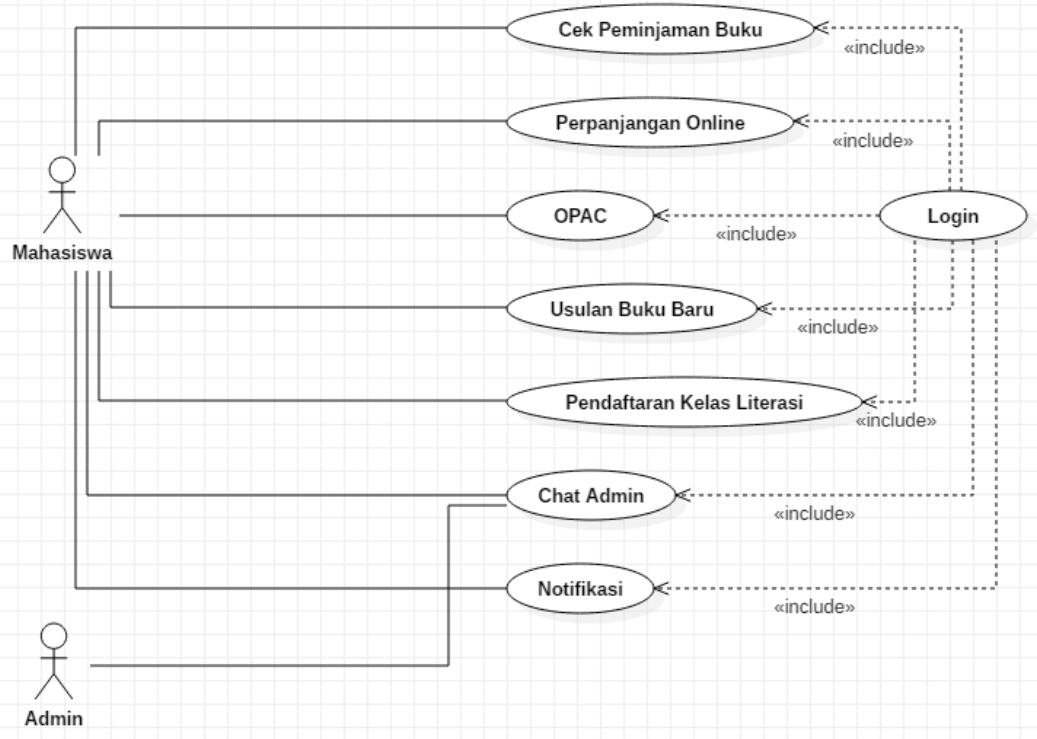

Gambar 2. Usecase Diagram

Mekanisme dalam Use Case Diagram dapat dijelaskan seperti dibawah ini:

Mahasiswa melakukan login dengan NIM dan PIC, setelah login maka akan masuk ke menu utama. Dalam menu utama mahasiswa dapat melakukan cek peminjaman buku, perpanjangan online, pencarian koleksi, mengusulkan buku baru, mendaftar kelas literasi, dapat melakukan kritik dan saran, dapat chat dengan admin, dan mendapatkan notifikasi waktu peminjaman dan keterlambatan pengembalian buku.

\subsection{Design}

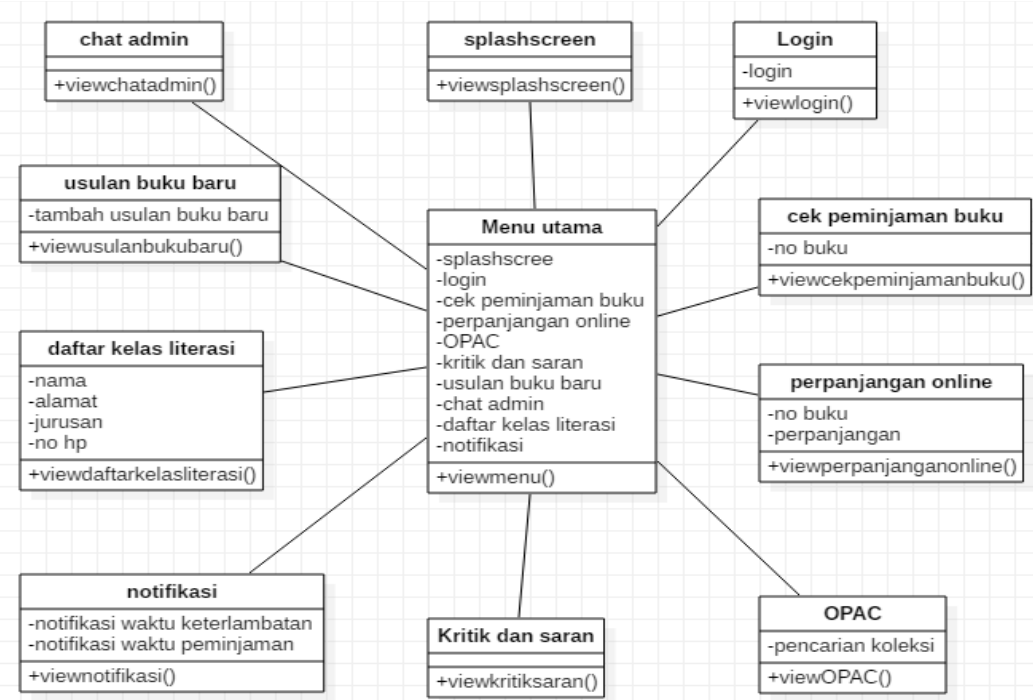

Gambar 3. Class Diagram

REPOSITOR, Vol. 2, No. 6, Juni 2020: 745-756 


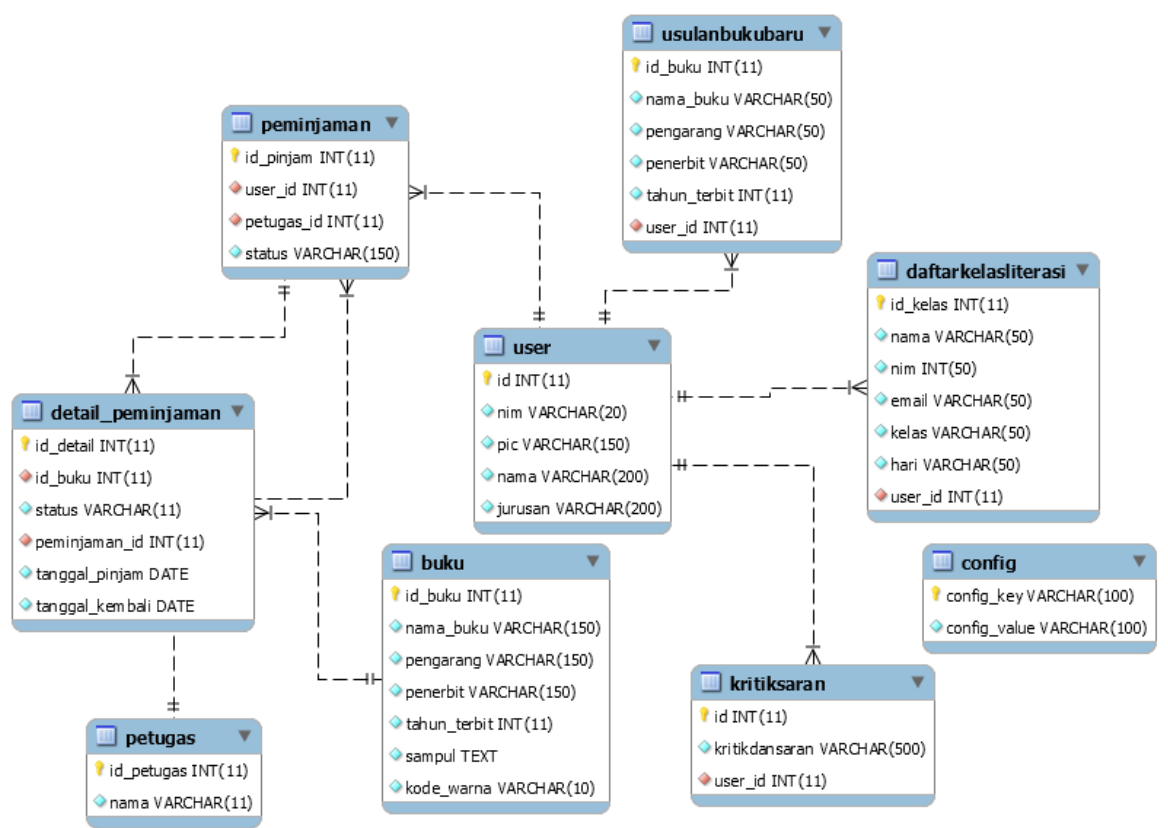

Gambar 4. ER Diagram

Pada tahapan ini penulis mendesain bagaimana sturktur sitem yang akan dibuat, sehingga menghasilkan beberapa diagram, diantaranya adalah class diagram dan ER diagram yang dapat dilihat pada Gambar 3 dan Gambar 4.

\subsubsection{Design Interface}

Desain antarmuka (interface) dirancang untuk mempermudah pengguna. bisa dilihat pada Gambar 5, Gambar 6, Gambar 7, Gambar 8, Gambar 9, Gambar 10, dan Gambar 11.

a. Interface Login

b. Interface Menu

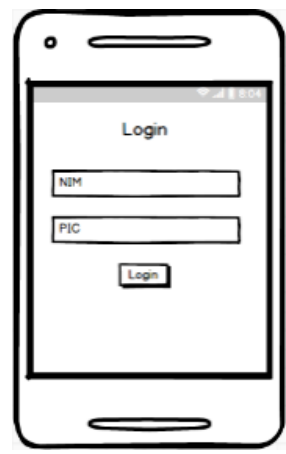

Gambar 5. Interface Login

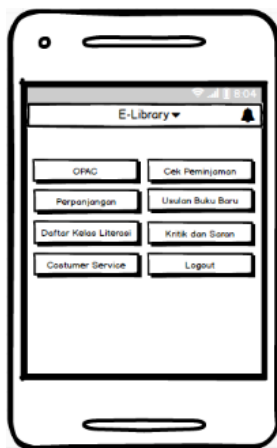

Gambar 6. Interface Menu

Pengembangan Sistem Perpustakaan Universitas Muhammadiyah Malang... Muhammad Ilham, Gita Indah Marthasari, Ilyas Nuryasin 
c. Interface Cek Peminjaman Buku

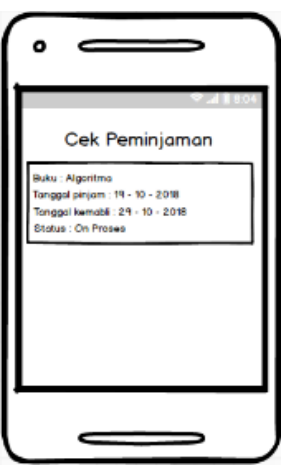

Gambar 7. Interface Cek Peminjaman Buku

a. Interface Katalog Buku

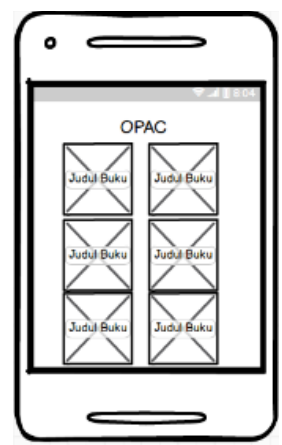

Gambar 8. Interface Katalog Buku

b. Interface usulan Buku Baru

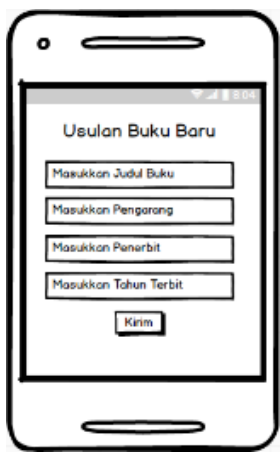

Gambar 9. Interface Usulan Buku Baru

c. Interface Daftar Kelas Literasi

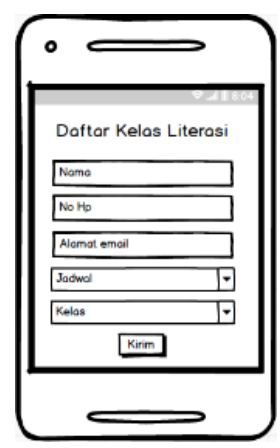

Gambar 10. Interface Daftar Kelas Literasi

REPOSITOR, Vol. 2, No. 6, Juni 2020: 745-756 
d. Interface Customer Service

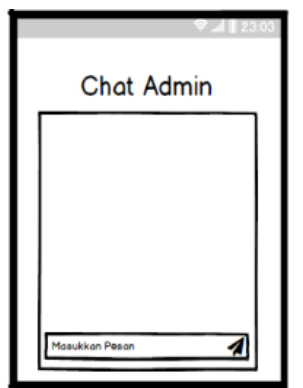

Gambar 11. Inteface Customer Service

\section{Hasil Penelitian Dan Pembahasan}

4.1 Implementation

Pada tahap ini dimana peneliti mulai mengimplementasikan code pemrograman dari hasil analysis dan design ke dalam sistem, sehingga menghasilkan beberapa screenshoot dari hasil pengimplementasian dari code pemrograman dapat dilihat pada Gambar 12, Gambar 13, Gambar 14, Gambar 15, Gambar 16, Gambar 17, dan Gambar 18.

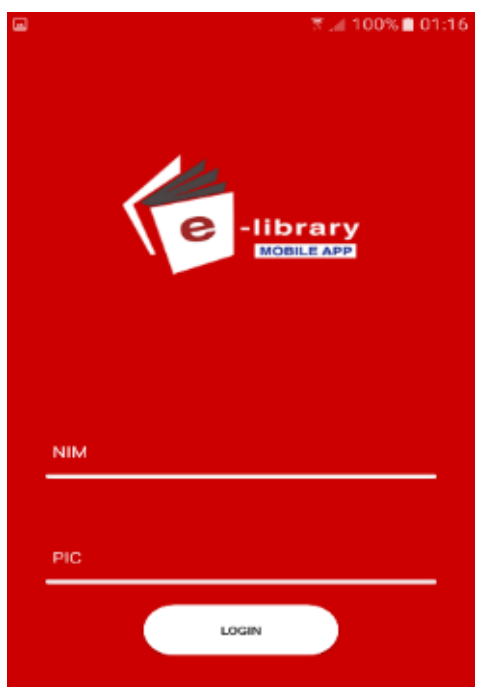

Gambar 12. Tampilan Login

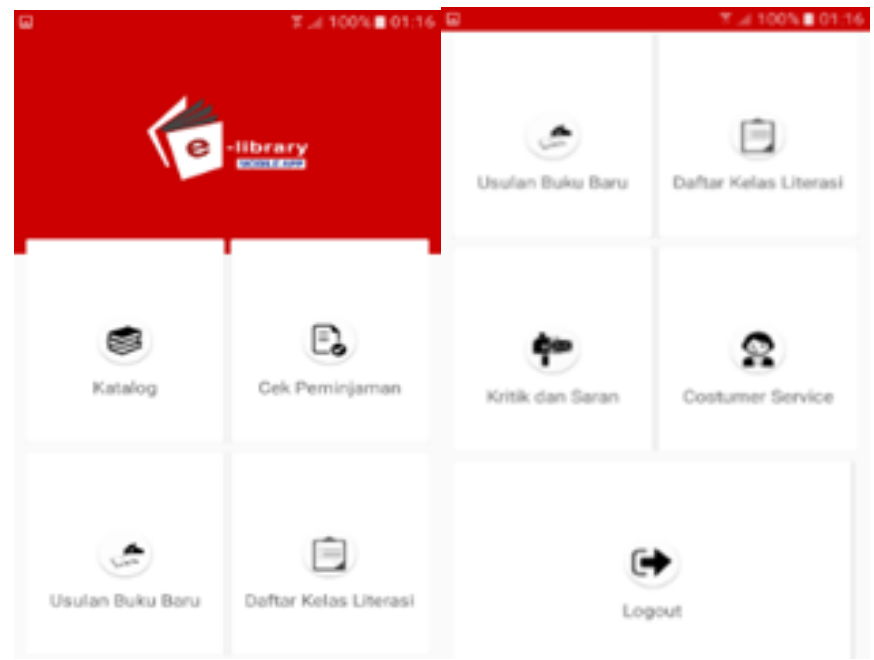

Tampilan 13. Tampilan Menu 


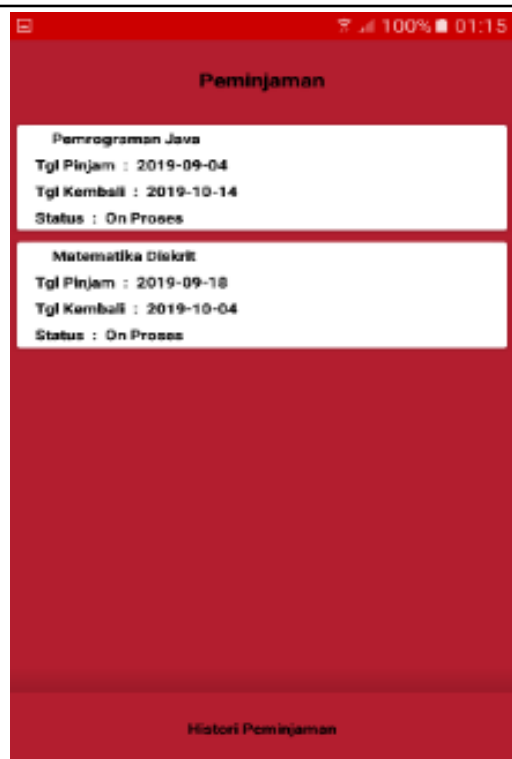

Gambar 14. Tampilan Cek Peminjaman

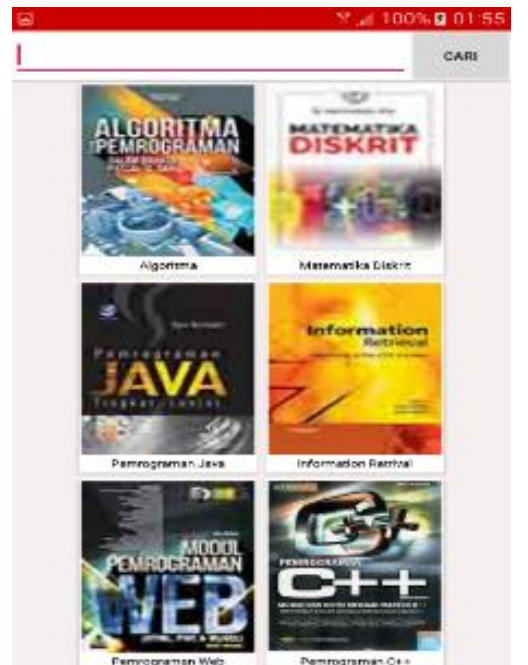

Gambar 15. Tampilan Katalog Buku

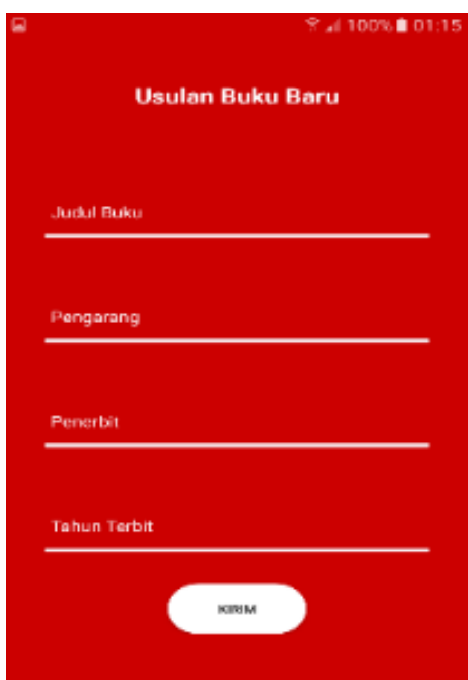

Gambar 16. Tampilan Usulan Buku Baru

REPOSITOR, Vol. 2, No. 6, Juni 2020: 745-756 


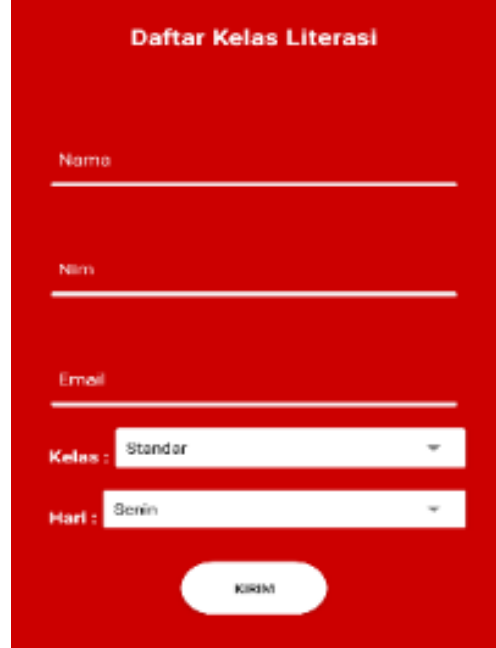

Gambar 17. Tampilan Daftar Kelas Literasi

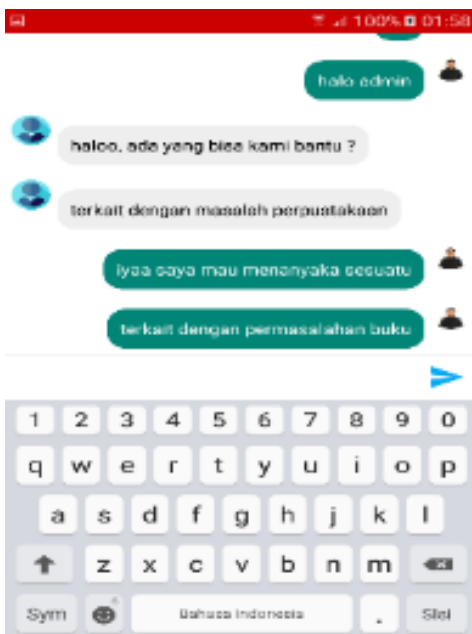

Gambar 18. Tampilan chat Customer Service

\subsection{Pengujian Sistem}

Dalam skenario pengujian langsung melibatkan pengguna yaitu mahasiswa. Nantinya mahasiswa langsung menggunakan aplikasi. Pengujian tersebut diantaranya pada Tabel 1, Tabel 2, dan Tabel 3.

a. Skenario Pengujian 1

Pada skenario pengujian 1, mahasiswa melakukan pengujian fitur login. Mahasiswa masuk ke dalam aplikasi perpustakaan Universitas Muhammadiyah Malang.

Tabel 1. Hasil Skenario Pengujian 1

\begin{tabular}{ccccc}
\hline Inputan & $\begin{array}{c}\text { Hasil yang } \\
\text { diharapkan }\end{array}$ & Pengamatan & Keterangan & Tampilan Aplikasi \\
\hline $\begin{array}{c}\text { 1. Mahasiswa } \\
\text { melakukan login } \\
\text { dengan tidak }\end{array}$ & $\begin{array}{c}\text { Terdapat } \\
\text { informasi }\end{array}$ & Login Gagal & Sesuai & \\
$\begin{array}{c}\text { mengisi data } \\
\text { disalah satu } \\
\text { form }\end{array}$ & $\begin{array}{c}\text { kesalahan } \\
\end{array}$ & & & \\
\hline
\end{tabular}




\begin{tabular}{|c|c|c|c|c|}
\hline $\begin{array}{l}\text { 2. Mahasiswa } \\
\text { melakukan login } \\
\text { dengan mengisi } \\
\text { data yang } \\
\text { sesuai }\end{array}$ & $\begin{array}{l}\text { Login } \\
\text { Berhasil, } \\
\text { masuk } \\
\text { menu utama }\end{array}$ & Login Sukses & Sesuai & $\sqrt{e-\text {-ubrary }}$ \\
\hline \multicolumn{5}{|c|}{ Tabel 2. Hasil Skenario Pengujian 2} \\
\hline Inputan & $\begin{array}{l}\text { Hasil yang } \\
\text { diharapkan }\end{array}$ & Pengamatan & Keterangan & Tampilan Aplikasi \\
\hline $\begin{array}{c}\text { 1.Mahasiswa } \\
\text { tidak mengisi } \\
\text { semua data pada } \\
\text { form usulan buku } \\
\text { baru }\end{array}$ & $\begin{array}{c}\text { Terdapat } \\
\text { kesalahan } \\
\text { informasi }\end{array}$ & $\begin{array}{c}\text { Usulan buku } \\
\text { baru gagal }\end{array}$ & Sesuai & \\
\hline $\begin{array}{l}\text { 2.Mahasiswa } \\
\text { mengisi semua } \\
\text { data pada form } \\
\text { usulan buku baru }\end{array}$ & $\begin{array}{c}\text { Usulan buku } \\
\text { baru } \\
\text { Berhasil }\end{array}$ & $\begin{array}{l}\text { Usulan buku } \\
\text { baru sukses }\end{array}$ & Sesuai & 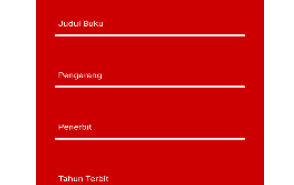 \\
\hline \multicolumn{5}{|c|}{ Tabel 3. Hasil Skenario Pengujian 3} \\
\hline Inputan & $\begin{array}{l}\text { Hasil yang } \\
\text { diharapkan }\end{array}$ & Pengamatan & Keterangan & Tampilan Aplikasi \\
\hline $\begin{array}{c}\text { 1.Mahasiswa } \\
\text { tidak mengisi } \\
\text { semua data pada } \\
\text { form pendaftaran } \\
\text { kelas literasi }\end{array}$ & $\begin{array}{c}\text { Terdapat } \\
\text { kesalahan } \\
\text { informasi }\end{array}$ & $\begin{array}{c}\text { Pendaftaran } \\
\text { kelas literasi } \\
\text { baru gagal }\end{array}$ & Sesuai & \\
\hline $\begin{array}{c}\text { 2.Mahasiswa } \\
\text { mengisi semua } \\
\text { data pada form } \\
\text { pendaftaran kelas } \\
\text { literasi }\end{array}$ & $\begin{array}{c}\text { Pendaftaran } \\
\text { kelas literasi } \\
\text { Berhasil }\end{array}$ & $\begin{array}{l}\text { Pendaftaran } \\
\text { kelas literasi } \\
\text { sukses }\end{array}$ & Sesuai & 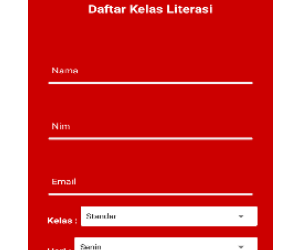 \\
\hline
\end{tabular}

\section{Kesimpulan}

Penjelasan dan uraian dari penjelasan dalam bab-bab di atas yang membahas meliputi semua aspek mulai dari yang menyangkut dengan analisa, perancangan, pembangunan, pengujian, serta implementasi pada Sistem Perpustakaan Universitas Muhammadiyah malang, maka kesimpulan yang didapat adalah sebagai berikut:

1. Pada Sistem Perpustakaan Universitas Muhammadiyah Malang berbasis Android ini merupakan sistem yang akan digunakan dalam hal yang terkait dengan semua kegiatan di Perpustakaan Universitas Muhammadiyah Malang.

2. Berdasarkan dari hasil pengujian yang telah dilakukan terhadap Sistem Perpustakaan Universitas Muhammadiyah Malang berbasis Android ini dapat dijelaskan dan dapat ditarik kesimpulan bahwa semua fungsi - fungsi sudah berjalan semuanya dengan baik dan sudah sesuai dengan yang diharapkan dan diinginkan oleh klien. 


\section{Referensi}

[1] Goyena, R. (2019). Perancangan dan Pembuatan E-Katalog Berbasis Android Pada Tee Company Yogyakarta. Journal of Chemical Information and Modeling,53(9),1689-1699. https://doi.org/10.1017/CBO9781107415324.004.

[2] Afriansyah, A. (2015). Politeknik Sekayu Menggunakan Pemrograman Java Aidil Afriansyah Program Studi Teknik Informatika Politeknik Sekayu Email: aidil.afriansyah@gmail.com. Jurnal Teknik Informatika Politeknik Sekayu (TIPS), III(2), 5361.

[3] Satria, D. (2017). Perancangan Sistem M-Library untuk Perpustakaan Universitas Sumatera Utara. Repositori Institusi USU Departemen, 1(1), 98.

[4] APJII. (2019). Penetrasi dan Perilaku Pengguna Internet Indonesia. Apjii, (Penetrasi dan Perilaku Pengguna Internet Indonesia), 1-34.

[5] Titan, T., Luhukay, D., \& Kurniawan, Y. (2014). Analisis dan Perancangan Sistem Informasi Perpustakaan Sma Negeri Xyz. ComTech: Computer, Mathematics and Engineering Applications, 5(1), 387. https://doi.org/10.21512/comtech.v5i1.2632

[6] Zain, A. (2017). Perancangan Aplikasi Mobile Library Pada Perpustakaan Sekolah Tinggi Teknologi Bontang Berbasis Android, XVI(2)

[7] Qamaruzzaman, M. H., \& Haris, F. (2017). Aplikasi Mobile Perpustakaan Berbasis Android (Studi Kasus Perpustakaan STMIK Palangka Raya). Jurnal SAINTEKOM, 6(1), 59. https://doi.org/10.33020/saintekom.v6i1.6.

[8] Sasmito, G. W. (2017). Penerapan Metode Waterfall Pada Desain Sistem Informasi Geografis Industri Kabupaten Tegal. Jurnal Informatika:Jurnal Pengembangan IT (JPIT), 2(1), 6-12. 
REPOSITOR, Vol. 2, No. 6, Juni 2020: 745-756 